\title{
Identifying Keys to Success in Innovative Teaching: Student Engagement and Instructional Practices as Predictors of Student Learning in a Course Using a Team- Based Learning Approach
}

ABSTRACT

When implementing innovative teaching techniques, instructors often seek to gauge the success of their methods. Proposing one approach to assessing classroom innovation, this study examines the ability of students' ratings of engagement and instructional practices to predict their learning in a cooperative (team-based) framework. After identifying the factor structures underlying measures of student engagement and instructional practices, these factors were used as predictors of self-reported student learning in a general chemistry course delivered using a team-based learning approach. Exploratory factor analyses showed a fourfactor structure of engagement: teamwork involvement, investment in the learning process, feelings about team-based learning, level of academic challenge; and a three-factor structure of instructional practices: instructional guidance, fostering self-directed learning skills, and cognitive level. Multiple linear regression revealed that feelings about team-based learning and perceptions of instructional guidance had significant effects on learning, beyond other predictors, while controlling gender, GPA, class level, number of credit hours, whether students began college at their current institution, expected highest level of education, racial or ethnic identification, and parental level of education. These results yield insight into student perceptions about team-based learning, and how to measure learning in a team-based learning framework, with implications for how to evaluate innovative instructional methods.

\section{KEYWORDS}

student engagement, student learning, team-based learning, general chemistry, predictors of learning outcomes

Student engagement has been regarded as a determining factor for promoting academic achievement (Astin, 1984; Fink, 2007; Kuh, Cruce, Shoup, Kinzie, \& Gonveya, 2008; Svanum \& Bigatti, 2009). Students who engage with course content to a greater degree experience greater success (Astin, 1984). As a result, fostering student engagement is a critical challenge for instructors regardless of their disciplinary focus. Cooperative learning is among the teaching methods that are claimed to promote student engagement (Johnson, Johnson \& Smith, 2014). In the present study, a team-based learning approach — a form of cooperative learning (Michaelsen, Knight \& Fink, 2002) — was introduced to a university-level general chemistry course. We examined which aspects of student engagement, and of the team-based instructional strategy, best predicted student perceptions of learning in the course. 
Our goals were:

1. to offer insight into the relationship between engagement, instructional practices, and perceived learning in a cooperative, team-based course environment, and

2. to evaluate the factor structures of measures of engagement and instructional practices with utility for assessing innovative instructional methods.

Given that part of the challenge for engaging students requires understanding how and why teaching methods designed to enhance engagement impact student learning, consideration of both the theoretical context of engagement and practical basis for the implementation of team-based learning is necessary.

\section{CONCEPTUALIZING STUDENT ENGAGEMENT}

In his theory of student involvement, Astin (1984) defines student involvement (i.e., engagement) as "the amount of physical and psychological energy that the student devotes to the academic experience" (p.518). The theory supports the view that learning is maximized when the learning environment is designed to encourage students' active participation. Educators should, according to Astin, devote more time and energy to gauging and stimulating students' motivation and the amount of effort they dedicate to the learning process.

The empirical literature confirms the importance of student involvement or engagement for learning. For instance, Svanum et al. (2009) studied student engagement among undergraduate students enrolled in an upper division course in abnormal psychology. They examined whether academic course engagement, measured as course involvement and effort directed toward specific course componentssuch as attending lectures and completing reading assignments - predicted baccalaureate degree attainment and the proficiency and efficiency with which students reached this goal. They concluded that although — to some extent—college success relates to previously acquired skills and academic ability, what students do in college and the degree to which they become involved also impacts success. Astin's theory (1984) of involvement along with the empirical findings of Svanum et al. (2009) suggest that engagement is multidimensional, containing not only skill-effort components but also an interpersonal component. Relatedly, other researchers argue that addressing the interpersonal component of engagement by implementing teaching methods that promote interactions with teachers and other students can stimulate and sustain engagement (Guthrie, Anderson, Alao, \& Rinehart, 1999; Pintrich \& De Groot, 1990; Skinner \& Belmont, 1993). Additionally, reward, reinforcement, or gratification are considered crucial in the acquisition and performance of skills and knowledge (Rotter, 1996).

\section{ENGAGING STUDENTS THROUGH COOPERATIVE LEARNING}

Given the stated importance of students playing an active and involved role in the learning process, how can student engagement be promoted in the classroom? According to a number of studies, active participation in learning can be accomplished through cooperative learning with group activities (Knabb, 2000; Rassuli \& Manzer, 2005; Springer, Stanne, \& Donovan, 1999). Several meta-analyses of the effects of cooperative learning on various outcomes (Johnson, Johnson, \& Smith, 2014; Springer et al., 1999) reveal that cooperative learning has favorable effects on academic achievement, encourages positive relationships with classmates and faculty, improves psychological health and well-being, promotes more favorable attitudes toward learning, and increases persistence through science, mathematics, engineering, and technology courses and programs. According to Springer et al. (1999), 
there are three interrelated theoretical perspectives that describe the effects of small-group learning on academic achievement: motivational, affective and cognitive.

First, from the motivational standpoint, the key to promoting a cooperative learning environment lies on the implementation of group goals and instructional structure that holds each group member accountable for learning. Group members will support each other if they think that the success of the group is important. Individual accountability helps to ensure that students interact and support one another in ways that lead to significant learning.

Second, the affective perspective of the effects of small-group learning on academic achievement is grounded on the conception that group work that takes place in an encouraging atmosphere is likely to promote learning. When instructors facilitate supportive and open interactions among group members that are characterized by high-level discussions, greater conceptual understanding is achieved by the students (Johnson \& Johnson, 1985; Smith, Johnson, \& Johnson, 1981).

Third, the cognitive perspective contends that interactions between students cause an increase in achievement because they provide more opportunities for information processing. While engaging in discussions of the course content, disagreements in reasoning will arise, multiple paths leading to the same solution will be uncovered, students will engage in cognitive restructuring of the material, and the development of higher-order thinking will result (Johnson \& Johnson, 1985; Smith et al., 1981).

\section{TEAM-BASED LEARNING}

As one of the approaches to cooperative learning, team-based learning is an active learning strategy that promotes student engagement (Clark, Nguyen, Bray \& Levine, 2008; Haidet, Morgan, O’Malley, Moran, \& Richards, 2004; Prince, 2004), increases test performance (Koles, Stolfi, Borges, Nelson, \& Parmelee, 2010), promotes positive student attitudes toward group work (Parmelee, DeStephen, \& Borges, 2009), and develops professional competencies that are difficult to nurture or assess through lecture-based instruction (Beatty, Kelley, Metzger, Bellebaum, \& McAuley, 2009; Parmelee and Michaelsen, 2010). Team-based learning is, moreover, an application-oriented pedagogical strategy (Thompson, Schneider, Haidet, Perkowski, \& Richards, 2007) that is believed to promote high levels of active student participation by integrating small groups into a large class (Haidet \& Fecile, 2006).

Team-based learning (TBL), specifically, in contrast to other forms of cooperative, small group learning, makes group work the primary in-class activity (Michaelsen, Knight, \& Fink, 2002) and often requires a change in the structure of the course to develop and take advantage of the special capabilities of high-performance learning teams. Fink (2002) defines team-based learning using two key ideas. One is that TBL involves the formation of social units that are quite different from "groups" in the sense that the social units are characterized by a high level of individual commitment to the welfare of the group and high levels of trust among the members of the group. The process by which a group of students becomes a "team" requires a) time for members to interact, b) scholarly resources, c) challenging tasks that become common goals, and d) frequent feedback on individual and group performance. A second key idea is that team-based learning is not simply a series of disconnected group activities, but a particular instructional strategy that often requires a complete course redesign. The restructuring of the course involves dividing the material into five to seven modules focused on the core topics of the subject.

A three-phase sequence is incorporated within each module: preparation, application, and assessment, and this sequence of interdependent activities, tailored to dynamically engage students in the learning process, reflects the motivational, cognitive and affective perspectives of learning in a 
cooperative context (Springer et al., 1999). Next, we describe this sequence further, conceptually and as implemented in a redesigned general chemistry course.

\section{TBL phase 1: preparation}

The goal of the preparation phase is that students familiarize themselves with the core concepts corresponding to a module. This was accomplished outside the classroom through completion of instructor-guided reading assignments or through watching instructional videos. Next, once in the classroom, students engaged in a readiness assurance process in which they were tested on fundamental concepts. Immediately after students submitted their individual answers, they repeated the same test as a team. Following the group quiz, teams had the opportunity to appeal wrong answers if they were due to ambiguity in the questions. Teams were required to provide evidence and create a convincing written argument as to why their answer was correct. In the final step, the instructor provided clarification of any misconceptions the students had. The preparation phase most closely reflects the motivational perspective of cooperative learning (Springer at al., 1999).

\section{TBL phase 2: application}

In this second phase, teams apply the concepts reviewed in the readiness assurance process to solve problems which require answering questions, creating explanations, or making predictions. Teams submitted their answers to class problems simultaneously, and the instructor offered feedback on the quality of the responses. This exercise allowed students to consider different approaches to solve a problem, to compare their reasoning with that of classmates, and to construct new ways of thinking. The application phase thus most closely reflects the affective and cognitive perspectives of cooperative learning.

\section{TBL phase 3: assessment}

The sequence of interdependent activities for each module in team-based learning ends with the assessment phase, in which students take a comprehensive test on the module's content. Following the assessment phase for the first module, teams integrated previous material with new information as they iteratively repeated the cycle with each subsequent module.

\section{OVERVIEW OF THE CURRENT STUDY}

Although studies on the use of TBL in the instruction of undergraduate communication (Thomas, 2012), entrepreneurship (Drummond, 2012), information technology (Jacobson, 2011), law (Dana, 2007), mathematics (Paterson \& Sneddon, 2011), nursing (Clark, Nguyen, Bray, \& Levine, 2008), statistics (Clair \& Chihara, 2012), and psychology (Grant-Vallone, 2011; Thomas \& McPherson, 2011) courses have been reported, the use of TBL in the instruction of an undergraduate general chemistry course has not been highlighted. In this study, following a full course redesign to integrate TBL, we surveyed general chemistry students' perceptions of engagement, instructional practices, and learning. Students' responses were analyzed and, after evaluating their factor structure and reliability, the predictive value of these student engagement constructs and instructional practices on self-reported learning was examined.

\section{METHODOLOGY}

An online survey was used to assess students' perceptions of engagement, instructional practices, and learning outcomes. Exploratory factor analyses using principal axis factoring with Direct Oblimin 
rotation were conducted on the engagement and instructional practices items to identify their factor structures. The relationship between engagement and instructional practices on student learning was examined by employing multiple linear regression.

\section{Participants}

All undergraduate students $(\mathrm{N}=111)$ enrolled in a section of a 14-week General Chemistry II course at a 4-year degree public university in eastern North Carolina were invited to participate in this study. Response rates to the online survey questions ranged from 108/111 (teamwork and feelings items) to $102 / 111$ for the class status item (Table 1). The demographics of our non-randomized sample are representative of the students in the course under study. Nearly $57 \%$ of the participants were women; $71 \%$ of participants classified themselves as White. The majority of the participants were fulltime students (96\%) and most of them had a self-reported GPA 3.0 or above (86\%).

Students were invited to participate by email and provided electronic consent by answering the first question in the survey (' ... Do you consent to participate in this study?'). Additionally, the instructor read an invitation to participate aloud during class. Participation was voluntary and no monetary compensation was provided, but extra credit was granted. The research study was approved by the lead author's Institutional Review Board.

Table 1. Descriptive statistics

\begin{tabular}{|c|c|c|c|c|}
\hline Variable & $\mathrm{n}$ & $\%$ & Mean* & S.D. \\
\hline \multicolumn{5}{|l|}{ Gender } \\
\hline Male & 46 & 43.4 & -- & -- \\
\hline Female & 60 & 56.6 & -- & -- \\
\hline \multicolumn{5}{|l|}{ Ethnicity } \\
\hline Asian & 9 & 8.6 & -- & -- \\
\hline Black or African American & 10 & 9.5 & -- & -- \\
\hline Hispanic or Latino & 9 & 8.6 & -- & -- \\
\hline White & 75 & 71.4 & -- & -- \\
\hline Other & 2 & 1.9 & -- & -- \\
\hline \multicolumn{5}{|l|}{ Class } \\
\hline Freshman & 45 & 44.1 & -- & -- \\
\hline Sophomore & 34 & 33.3 & & . \\
\hline Junior & 17 & 16.7 & -- & -- \\
\hline Senior & 6 & 5.9 & -- & -- \\
\hline \multicolumn{5}{|l|}{ Engagement } \\
\hline Teamwork & 108 & & 4.15 & .67 \\
\hline Reaching out & 106 & & 2.20 & 1.08 \\
\hline Feelings & 108 & & 3.71 & .76 \\
\hline Personal investment & 106 & & 3.95 & .67 \\
\hline \multicolumn{5}{|l|}{ Instructional practices } \\
\hline Cognitive & 107 & & 3.80 & .76 \\
\hline Opportunities & 105 & & 4.50 & .77 \\
\hline Guidance & 106 & & 4.31 & .84 \\
\hline Self-reported student learning & 106 & & 4.04 & .85 \\
\hline
\end{tabular}


*Scale of 1 to 5 with 5 indicating greater levels of the characteristics being measured. Totals that are less than the total number of participants $(\mathrm{N}=108)$ reflect non-responses.

\section{Materials}

The survey consisted of 81 items, including four sections: demographic information (12 items), student engagement (43 items), instructional practices (20 items), and self-reported student learning (6 items).

\section{Demographics}

Participants were asked to report their gender, racial/ethnic identification, GPA, class level, whether they were full-time students, number of credit hours for which they were enrolled, at what institution they began college, highest level of education they expected to complete, highest level of education completed by either parent, whether they were members of a sorority or fraternity, whether they had been diagnosed with any disability or impairment, and, if they had been diagnosed with a disability or impairment, the type of disability or impairment.

\section{Student engagement}

The student engagement questions were created by adapting selected items from the National Survey of Student Engagement (NSSE) instrument (2012). The items chosen were intended to measure primarily the behavioral dimension of engagement and to identify effective educational practices that support such behaviors. Since the NSSE is designed to reflect general engagement in school, most of the items were reworded in order to make them specific to the General Chemistry II course and to the TBL teaching strategy. In addition, items reflecting psychological components of engagement were also incorporated in the survey in order to gain better understanding of all aspects of engagement that may promote student learning. These items were adapted from Louis and Schreiner's Engaged Learning Index (Schreiner \& Louis, 2011).

The resulting student engagement scale included 43 items reflecting how often students engaged in collaborative learning (e.g., "Asked questions during group discussions"; 1 [ never] to 5 [all of the time]), students' feelings about the particular course (e.g., "How often you felt that the interaction with your teammates helps you increase understanding of the course material"; 1 [never] to 5 [all of the time]), students' self-regulation (e.g., "Identified key information from reading assignments, videos, or PowerPoint lecture slides"; 1 [very much] to 5 [not at all]), and the number of hours students allocated to academic, personal, and co-curricular activities in a typical 7-day week ( 0 hours, 1-5 hours, 6-10 hours, 11-15 hours, 16-20 hours, 21-25 hours, 26-30 hours). These items are indirectly related to the motivational, affective, and cognitive perspectives of the effect of small-group learning on academic outcomes as they reflect students' behaviors that may influence their learning outcomes.

\section{Instructional practices}

Next, participants responded to 20 items involving students' perceptions of the guidance and feedback provided by the instructor (e.g., "Clearly explained course goals and requirements"; 1 ([very much] to 5 [not at all]), the extent to which the instructor provided opportunities for the development of self-regulated learning skills (e.g., "Providing opportunities for students to take initiative and responsibility for their own learning"; 1 [very much] to 5 [not at all]), and how much different levels of learning were emphasized in the particular course (e.g, "Analyzing the basic elements of an idea, 
experience, or theory such as examining a specific issue/problem in depth and considering its components"; 1 [very much] to 5 [not at all $]$ ).

\section{Perceived learning}

To assess students' perceptions of learning outcomes, six items selected from the NSSE survey instrument (2012) were used. The items gathered students' perceptions of their gains in higher-order thinking skills ("Thinking critically and analytically", "Analyzing numerical information”), work-related competencies ("Expressing ideas clearly and effectively"), group skills ("Working effectively with others"), and self-directed learning skills ("Learning effectively on your own"). All items used a fivepoint scale: 1 (very much) to 5 (not at all). Internal consistency of the self-reported student learning items was analyzed using Cronbach's reliability test (alpha $=.947)$.

\section{Data Analysis}

Data analyses was performed using the Statistical Package for the Social Sciences (SPSS) version 22.0. All statements in the survey instrument utilizing 1 [very much] to 5 [not at all] response scales were reverse-scored prior to analysis in a manner consistent with higher numbers equaling more of the attribute (e.g. higher engagement, higher effectiveness of instructional strategy and greater learning outcomes). Exploratory factor analysis (EFA) was conducted on the engagement and instructional practices items to collapse the large number of variables contained in each set into a few interpretable underlying factors. A principal axis factoring analysis with Direct Oblimin rotation was undertaken to identify the factor structure for each scale. Parallel analysis (O'Connor, 2000) was used to determine the number of factors for each scale. Total scores for each factor obtained from EFA were computed. As for item performance, reliability analysis was conducted for each scale. Bivariate correlation analyses were performed to assess collinearity among potential predictors of self-reported student learning. In order to determine which components of engagement and instructional practices had impact on self-reported student learning, while controlling gender, GPA, class level, number of credit hours, whether students began college at the current institution, expected highest level of education, racial or ethnic identification, and parental highest level of education, multiple linear regression analysis was performed.

\section{RESULTS}

\section{Exploratory factor analysis: student engagement}

Principal axis factoring analysis with Direct Oblimin rotation was performed to identify the underlying factors of the engagement scale. The Kayser-Meyer-Olkin measure of sample adequacy was 0.78, suggesting that the data were sufficient relative to the number of items in the scale (Hutcheson \& Sofroniou, 1999). Barlett's test of sphericity, $\chi^{2}(378)=2093.12, p<.001$, showed that the correlations between the items were appropriate for factor analysis (Field, 2009). A scree plot from parallel analysis indicated a four-factor structure of student engagement. The cut-off criterion for item loadings was set to .40 (Stevens, 1992). Items with factor loadings smaller than .40 were removed. After examining item performance using item-total correlations and Cronbach's alpha, five items showing poor performance were removed ('Worked with other students outside of class time to complete class assignments or study for an exam', 'Included diverse perspectives in course discussions or assignments', 'Felt overwhelmed by the amount and intensity of the course work', 'Felt that you are not good at chemistry and that there is nothing you can do to become good at it', and 'Completed homework by the due date') and principal axis factoring was re-run. 
All four factors had moderately high factor loadings (Table 2; Osborne \& Costello, 2009). The first factor consisted of six items and was labeled 'feelings about the course.' These items reflect students' positive attitudes about the team-based learning pedagogical strategy and their interactions with classmates. The second factor, which consisted of seven items, was labeled 'reaching out for academic assistance' because these items reflected seeking additional help from or further discussion with instructors, teaching assistants, and tutors. The name given to the third factor, which consisted of eight items, was 'personal investment in the learning process' because it includes actions taken by students that help them achieve their educational goals as well as reflections on what they learned. The fourth factor, 'teamwork,' consisted of six items indicating students' active participation in collaborative learning.

Table 2. Four factor solution of engagement items

\begin{tabular}{|c|c|c|c|c|}
\hline Items & $\begin{array}{l}\text { Factor } 1 \\
\text { (Feelings) }\end{array}$ & $\begin{array}{l}\text { Factor } 2 \\
\text { (Reaching out) }\end{array}$ & $\begin{array}{l}\text { Factor } 3 \\
\text { (Personal } \\
\text { Investment) }\end{array}$ & $\begin{array}{l}\text { Factor } 4 \\
\text { (Teamwork) }\end{array}$ \\
\hline $\begin{array}{l}\text { Felt excited about the team-based learning } \\
\text { classroom }\end{array}$ & .80 & & & \\
\hline Felt fascinated about the course content & .72 & & & \\
\hline $\begin{array}{l}\text { Felt that chemistry is challenging for you but } \\
\text { that with hard work and a realistic study } \\
\text { strategy, you can excel }\end{array}$ & .42 & & & \\
\hline $\begin{array}{l}\text { Felt that you are a valuable member of your } \\
\text { learning team }\end{array}$ & .42 & & & \\
\hline $\begin{array}{l}\text { Felt that the interaction with your teammates } \\
\text { helps you develop your communication skills }\end{array}$ & .78 & & & \\
\hline $\begin{array}{l}\text { Felt that the interaction with your teammates } \\
\text { helps you increase understanding of the } \\
\text { course material }\end{array}$ & .75 & & & \\
\hline Attended weekly review sessions & & .57 & & \\
\hline Attended Tutoring Center tutorial sessions & & .51 & & \\
\hline Attended instructor's office hours & & .82 & & \\
\hline $\begin{array}{l}\text { Made an appointment with your instructor, a } \\
\text { tutor, or teaching assistant to get assistance }\end{array}$ & & .82 & & \\
\hline $\begin{array}{l}\text { Talked about career plans with your } \\
\text { instructor* }\end{array}$ & & .77 & & \\
\hline $\begin{array}{l}\text { Discussed course topics, ideas, or concepts } \\
\text { with your instructor outside of class* }\end{array}$ & & .87 & & \\
\hline $\begin{array}{l}\text { Discussed your academic performance with } \\
\text { your instructor* }\end{array}$ & & .91 & & \\
\hline $\begin{array}{l}\text { Fully completed the pre-class reading } \\
\text { assignments }\end{array}$ & & & .82 & \\
\hline $\begin{array}{l}\text { Reviewed the completed pre-class reading } \\
\text { assignments before attending the } \\
\text { corresponding class meeting }\end{array}$ & & & .82 & \\
\hline $\begin{array}{l}\text { Watched videos suggested by your instructor } \\
\text { as a way to prepare for class meetings }\end{array}$ & & & .60 & \\
\hline
\end{tabular}




\begin{tabular}{lll}
\hline $\begin{array}{l}\text { Identified key information from reading } \\
\text { assignments, videos, or PowerPoint lecture } \\
\text { slides* }\end{array}$ & .72 & \\
\hline $\begin{array}{l}\text { Examined the strengths and weaknesses of } \\
\text { your own views on a topic or issue* }\end{array}$ & .51 & \\
\hline $\begin{array}{l}\text { Realized that you have learned something } \\
\text { that changed the way you understand an } \\
\text { issue or concept* }\end{array}$ & .53 \\
\hline $\begin{array}{l}\text { Taken advantage of available learning } \\
\text { resources }\end{array}$ & .48 \\
\hline $\begin{array}{l}\text { Summarize what you learned in class or from } \\
\text { course material provided }\end{array}$ & .83 \\
\hline Asked questions during group discussions* & .85 \\
\hline Contributed to group discussions & .63 \\
\hline Worked with other students during class time & .69 \\
\hline $\begin{array}{l}\text { Explained course material to one or more } \\
\text { classmates in the classroom* }\end{array}$ & .78 \\
\hline $\begin{array}{l}\text { Had a classmate explain course material to } \\
\text { you in the classroom }\end{array}$ & .56 \\
\hline $\begin{array}{l}\text { Reflected on feedback provided by your } \\
\text { teammates regarding your contribution to } \\
\text { team work }\end{array}$ & \\
\hline
\end{tabular}

*Items used with permission from The College Student Report, National Survey of Student Engagement, Copyright 2001-17 The Trustees of Indiana University.

To examine the reliability of the identified factors, internal consistency was assessed using Cronbach's alpha. Feelings about the course $(\alpha=.88)$, reaching out for academic assistance $(\alpha=.91)$, personal investment in the learning process $(\alpha=.88)$, and teamwork $(\alpha=.90)$ had strong internal consistency.

\section{Exploratory factor analysis: instructional practices}

For items grouped in the instructional practices set, the Kaiser-Meyer-Olkin measure of sample adequacy was .86 , indicating that the data were sufficient relative to the number of items in the scale (Hutcheson et al., 1999). Barlett's test of sphericity, $\chi^{2}(190)=2293.545, p<.001$, showed that the correlations between the items were appropriate for factor analysis (Field, 2009). A scree plot from parallel analysis was also used to determine the number of factors. Only factors for which the eigenvalues were greater than 1.00 (Pett, Lackey, \& Sullivan, 2003) were retained. The eigenvalues for the first three factors were 9.49, 3.25, and 2.25; however, the fourth eigenvalue (0.584) was lower than 1.00, which indicated that only three factors should be retained for analysis. The three-factor structure that was identified is presented in Table 3.

The factor loadings for the instructional practices set were robust. The factors were named instructional guidance (Factor 1), cognitive level (Factor 2), and fostering self-regulation (Factor 3). The instructional guidance factor contained nine items reflecting the instructor's guidance and feedback as well as the clarity and organization of learning activities. The six items comprising the cognitive level factor address the degree to which students perceived different levels of knowledge and cognitive 
processes as being nurtured by the instructional practices used. The third factor, fostering selfregulation, consists of six items that reflect opportunities provided for developing self-regulated learning skills.

Table 3. Three factor solution for instructional practices items

\begin{tabular}{llll}
\hline Items & Factor 1 & Factor 2 & Factor 3 \\
(Instructional & (Cognitive level) & $\begin{array}{l}\text { (Fostering self- } \\
\text { regulation) }\end{array}$
\end{tabular}

\begin{tabular}{ll}
\hline Clearly explained course goals and requirements* & .92 \\
\hline $\begin{array}{l}\text { Clearly described what students are expected to } \\
\text { do to prepare for each class meeting }\end{array}$ & .90 \\
\hline $\begin{array}{l}\text { Clearly described the activities that will take place } \\
\text { during each class session and the order in which } \\
\text { they will occur }\end{array}$ & .86 \\
$\begin{array}{ll}\text { Used examples or illustrations to explain difficult } \\
\text { points* }\end{array}$ & .89 \\
\hline $\begin{array}{l}\text { Incorporated class activities that promote self- } \\
\text { reflection }\end{array}$ & .75 \\
\hline $\begin{array}{l}\text { Provided guidance and feedback during the } \\
\text { active-learning class activities }\end{array}$ & .93 \\
\hline $\begin{array}{l}\text { Provided prompt feedback on tests or completed } \\
\text { assignments* }\end{array}$ & .81 \\
\hline $\begin{array}{l}\text { Encouraged collaborative work } \\
\text { Provided advice on how to prepare for an exam }\end{array}$ & .72 \\
\hline $\begin{array}{l}\text { Memorizing facts, ideas, or methods from your } \\
\text { course and readings so you can repeat them in } \\
\text { almost the same form* }\end{array}$ \\
\hline
\end{tabular}

Analyzing the basic elements of an idea, experience, or theory such as examining a specific issue/problem in depth and considering its

components*

Reaching conclusions based on your own analysis

of numerical information (numbers, graphs,

statistics, etc. $)^{*}$

Evaluating a point of view, decision, or information source (i.e., examining how others gathered and interpreted data and assessing the accuracy of their conclusions) ${ }^{*}$

Applying theories or methods to practical problems or new situations* 
Providing opportunities for students to take initiative and responsibility for their own learning

.93

Providing support to help students succeed

academically

.92

Encouraging students to identify and use learning

support services

.92

Providing opportunities for students to build

collaboration and communication skills

Providing opportunities for students to identify

and address gaps in their learning

.97

*Items used with permission from The College Student Report, National Survey of Student Engagement, Copyright 2001-17 The Trustees of Indiana University.

Cronbach's alphas for all three factors - instructional guidance $(\alpha=.96)$, cognitive level $(\alpha=.90)$, and fostering self-regulation $(\alpha=.97)$ — confirmed strong internal consistency.

\section{Multiple linear regression}

Each of the student engagement factors (feelings toward the course, reaching out for academic assistance, personal investment in the learning process, and level of participation in teamwork) and each of the instructional practices factors (instructional guidance, cognitive level, and opportunities for selfregulation) were used in a standard regression analysis to predict student self-reported learning. The factor scores were computed by averaging item total scores (see Table 1). Bivariate correlation analyses indicated that correlation coefficients between independent variables were below the threshold $|\mathrm{r}|>.7$ (Table 4) that is considered an appropriate indicator for when collinearity begins to severely distort model estimation and subsequent prediction (Dormann et al., 2013; Meyers, Gamst, \& Guarino, 2006).

Table 4. Correlations for engagement, instructional strategy $(n=105)$

\begin{tabular}{llllllll}
\hline Variables & 1 & 2 & 3 & 4 & 5 & 6 & 7 \\
\hline 1. Feelings & -- & .20 & .45 & .61 & .25 & .46 & .57 \\
\hline 2. Reaching out & & -- & .30 & -.04 & .26 & .08 & -.16 \\
\hline 3. Personal investment & & & -- & .46 & .53 & .51 & .36 \\
\hline 4. Teamwork & & & -- & .27 & .27 & .59 \\
\hline 5. Cognitive Level & & & & -- & .33 & .21 \\
\hline 6. Guidance & & & & & -- & .56 \\
\hline 7. Fostering self-regulation & & & & & & - \\
\hline
\end{tabular}

Demographic characteristics such as students' gender, race, intellectual ability (as measured by GPA), their educational aspirations, and the educational level attained by their parents are among the factors presumed to affect students' learning (Artino, 2007; Astin, 1993; Friday, et al., 2006; Oakes, 1990; Pascarella \& Terenzini, 2005). As this study is centered on investigating the relationship between learning and a particular set of independent variables (teamwork, reaching out, feelings about the course, personal investment, levels of learning, opportunities for developing self-regulated skills, instructor's guidance), to adjust for any possible influence by the demographic characteristics included on our 
survey, we used them as control variables for the multiple linear regression analysis. Male served as the reference group for gender. GPA was coded as three dummy variables, with GPA $=3.0$ serving as the reference group (see Table 5). Class level was coded as three dummy variables with freshmen serving as the reference group.

The full multiple linear regression model with independent variables and control variables was significant, $F(18,82)=9.85, p<.001$ and produced an adjusted $\mathrm{R}^{2}=.68$, which indicates that the predictors in this model explained $68 \%$ of the variance of student self-reported learning. Only two predictors, feelings about the course $(B=.63, p=.00)$ and instructional guidance $(B=.24, p=.01)$, emerged as statistically significant (see Table 5). Using the standardized coefficients to compare the two significant predictors, the following order of importance is noted: feelings (.56), and guidance (.24). Higher values for each of these predictors are associated with greater student learning while controlling other predictors in the model.

Table 5. Linear regression results (unstandardized slope, standard error, standardized betas and probability values)

\begin{tabular}{lllll}
\hline Predictors & $B$ & $S E$ & $\beta$ & $p$ \\
\hline Feelings & .63 & .11 & .56 & $.00^{*}$ \\
\hline Reaching out & -.01 & .07 & -.01 & .94 \\
\hline Personal investment & .26 & .13 & .20 & .054 \\
\hline Teamwork & -.18 & .13 & -.14 & .16 \\
\hline Cognitive Level & .12 & .09 & .10 & .19 \\
\hline Guidance & .24 & .09 & .24 & $.01^{*}$ \\
\hline Fostering self-regulation & -.04 & .11 & -.03 & .75 \\
\hline Gender: Female vs. Male & .20 & .12 & .11 & .11 \\
\hline GPA & & & & \\
\hline $3.7-4.0$ & .28 & .22 & .14 & .20 \\
\hline 3.3-3.6 & .10 & .19 & .05 & .61 \\
\hline 3.0-3.2 & .25 & .19 & .13 & .20 \\
\hline Class Level & & & & \\
\hline Sophomore & .29 & .14 & .16 & $.045^{*}$ \\
\hline Junior and Senior & -.01 & .23 & -.01 & .97 \\
\hline Credit hours & -.09 & .04 & -.17 & $.02^{*}$ \\
\hline Begin college here & -.03 & .22 & -.01 & .88 \\
\hline Expected highest level of education: Master or higher & -.08 & .14 & -.04 & .55 \\
\hline Race: White vs. others & .01 & .13 & .01 & .92 \\
\hline Highest level of education completed by parents & -.01 & .04 & -.02 & .82 \\
\hline
\end{tabular}

The reference group for gender is male.

The reference group for GPA is 3.0.

The reference group for class level is freshmen.

The reference group for expected highest level of education is bachelor or lower.

The reference group for begin college here is began college elsewhere.

${ }^{*} p<.05$. 


\section{DISCUSSION}

What features of student engagement and of the instructional practices used in this study best predict student learning? Our data suggest the answer is twofold: students' feelings about the course ( $\beta$ $=.56)$ and students' perceptions of the extent to which instructional guidance was provided $(\beta=.24)$ both significantly predicted self-reported learning. Closely following these two factors was a thirdpersonal investment in the learning process $(\beta=.20, p=.054)$ — which we also consider in the following discussion.

\section{Feelings about the course}

Our findings suggest that the more students felt excitement toward team-based learning, the greater their perceptions that team-based interactions were helpful, and the more fascinated they reported being by the course content, the more they judged themselves as having gained higher order thinking skills, work-related competencies, group skills and self-directed learning skills. There are at least two interpretations of the causality of this relationship. The first is that student responsiveness to the course structure — characterized by positive feelings about a team-based approach to chemistry-leads to the perception of superior learning. The second is that students who felt they learned more came to feel positively toward TBL and the course more generally (i.e., the reverse causal interpretation). Though the present study is cross-sectional and lacks a non-TBL comparison group, and thus cannot definitively address causality or the unique effect of course design on our outcomes, we view it as entirely possible that the inherent features of team-based learning served as a vehicle for improving students' feelings toward the course, and-as our analysis shows - more positive feelings toward a general chemistry course lead to greater learning. To the extent that students experienced substantial cognitive engagement, they consequently developed more positive attitudes toward learning chemistry. TBL is designed to promote high levels of student interactivity, in part, by providing an atmosphere in which learning is fueled not only by peer support but also by peer challenge. Students also build relationships with their teammates that go beyond mere academic work. Within each team, acquaintances may evolve into friendships. The positive interpersonal relationships fostered by TBL can serve as a mechanism by which TBL increases students' desire and ability to learn. As evidenced by the statement below, made by a student, the ongoing social interactions that are possible by being with the same group of peers for the whole academic term gives rise to a supportive network that stimulates learning.

\section{It (TBL) helps build up my confidence and it helps me see how the other team members solve this problem. By socializing together, we learn more.}

Our interpretation is consistent with Springer, Stanne and Donovan's (1999) affective perspective on the effects of small-group learning on academic achievement. According to the affective viewpoint, group work that takes place in an encouraging atmosphere is likely to promote learning. In the TBL framework used in this redesigned course, students had the opportunity to feel that they were valuable members of a group and that the interaction with their peers, teaching assistants and instructor helped them enhance their feelings of self-efficacy in chemistry. This outcome is consistent with students having more positive attitudes toward learning chemistry and, consequently, experiencing greater cognitive engagement in a TBL context. These findings are also consistent with the control-value theory of achievement emotions (Pekrun \& Perry, 2014). According to this theory, emotions influence students' academic performance and are linked to motivation, use of learning strategies, and self- 
regulation. Providing students with learning environments that stimulate autonomy and cooperation are presumed to foster students' sense of competence, which positively impacts their emotions (Pekrun, 2006).

\section{Instructional guidance}

Second only to their feelings about the course, the perceived degree of instructional guidance was significantly and positively related to students' gains in higher-order thinking skills, group skills and self-regulatory learning skills. These results suggest that students' learning can be positively impacted by clearly explaining course goals and expectations, using illustrations to explain difficult points, providing immediate and frequent feedback on course assignments and assessments, incorporating activities that promote self-reflection, and encouraging collaborative work. While these instructional practices are not unique to team-based learning, the implementation of practices such as providing immediate and frequent feedback, incorporating activities that promote self-reflection, and encouraging collaborative work is facilitated in the team-based learning framework. As proposed by the cognitive perspective of the effects small-group learning has on academic achievement (Springer et al., 1999), interactions between students increase achievement because they provide more opportunities for information processing. The discussions that take place within each team as well as among different teams expose students to ideas that challenge their assumptions and ways of thinking. When students are confronted with the alternative viewpoints of team members or other teams, they get immediate feedback and are placed in a position in which they have to think critically and elaborate on their views to defend them. By going through this process, students gain a deeper conceptual understanding.

The finding that instructional guidance is a significant predictor of students' learning can be further understood by taking into consideration that, in addition to containing subject-specific terminology, textbooks - particularly in chemistry—often require that readers make inferences to fill conceptual gaps, making comprehension of the course material challenging, even for skilled readers (Zwaan \& Singer, 2003). Researchers have suggested that to overcome comprehension difficulties, instructors should help students bridge the gaps between the content presented and text readings (Best, Rowe, Ozuru, \& McNamara, 2005). Our findings indicate that instructor interaction and guidance inside and outside of the classroom have an important impact on students' learning outcomes (cf. Cabrera, Colbeck, \& Terenzini, 2001).

\section{Additional predictors}

The personal investment factor, which reflects whether students engaged in a range of preparatory activities and interacted in meaningful ways with course material, each reflecting a commitment to the learning process, had an effect size on student learning that was only slightly behind instructional guidance. Several researchers have suggested that collaborative learning helps students develop and use the self-regulatory skills that might lead to these behaviors (Hadwin, Jarvela, and Miller, 2011; Kitsantas, Zimmerman and Cleary, 2000). That is, team-based learning is a form of collaborative learning that incorporates many of the processes that help students acquire skills described in Zimmerman's (2002) self-regulated learning model. Team problem-solving activities provide opportunities for students to observe, evaluate and monitor the work of peers as well as their own work, allowing them to acquire and emulate those skills and behaviors that are associated with greater learning (Kitsantas, Zimmerman and Cleary, 2000). Planning and allocating resources to meet task demands (Pintrich, 1990) is required of students in team-based learning, and includes those engagement activities comprising the personal investment factor: e.g., fully completing pre-class reading assignments, 
reviewing readings before attending class meetings, watching instructional videos suggested by the instructor as a way to prepare for class sessions, identifying key information, evaluating one's own views of a topic, summarizing what is learned during class activities or from course material provided, and taking advantage of available learning resources.

All other engagement factors (reaching out, teamwork) and instructional practices (cognitive level, fostering self-regulation) were non-significant predictors of self-reported learning. In some casessuch as for the teamwork factor-these findings are surprising and contrary to much of the research on team-based learning, which has generally reported positive associations between teamwork and learning (Beatty, Kelley, Metzger, Bellebaum, \& McAuley, 2009; Koles, Stolfi, Borges, Nelson, \& Parmelee, 2010; Parmelee \& Michaelsen, 2010). The present study found that feelings about team-based learning are a greater predictor of learning than the behaviors comprising our teamwork factor (e.g., asking questions during and participating in group discussions).

Though not the primary focus of the present study, examining our control variables revealed a pair of significant associations. First, sophomore (second-year) students reported greater learning outcomes than freshmen, but learning outcomes for juniors and seniors were not statistically different from those perceived by freshmen. Based on our data, we do not have a plausible explanation for these findings. More research is needed to examine how class level is associated with learning in a team-based learning environment.

Second, the negative standardized coefficient value for the number of credit hours for which students were enrolled $(\beta=-.17, p=.02)$ implies that self-reported learning decreases with increasing number of credit hours. This finding contradicts previous research indicating that students who take heavier academic loads achieve greater academic success (Abrams \& Jernigan, 1984). These incongruent findings suggest that the relationship between academic load and learning outcomes is complex and that further research investigating this association using a direct measure of learning, such as GPA, is deemed necessary.

\section{Limitations}

Considering that we did not seek to gather information for academic program assessment or accountability purposes, the study relied on self-report measures of gains in learning outcomes. According to Pike (2011), self-report data is appropriate for scholarly research in which the goal is to identify relationships among measures that are grounded in a theoretical framework- such as the relationships between those learning outcomes that are believed to be promoted through collaborative learning, selected student engagement constructs, and instructional practices. Further support for the validity of self-reports of educational outcomes as indicators of learning is provided by Anaya (1999). She conducted a direct comparison of college grade-point average (GPA), standardized test scores (GRE), and self-reports of learning gains, using a nationally representative sample of 2,289 students. Her results showed that self-reports of educational outcomes exhibited validity and produced comparable conclusions, regarding the impact of college on student learning, to those based on standardized tests and grade-point average measures. Thus, while objective learning outcomes are desirable when available, self-reports of learning gains are reasonable and efficient proxies.

Another limitation of this study is that the study was conducted in one institution using a small, non-randomized sample of students enrolled in a general chemistry course. Though our findings are consistent with past research (Fassinger, 1995; Nunn, 1996), the study needs to be replicated to determine whether the relationships found will hold true for other freshmen-level science courses that are delivered using similar collaborative, learner-centered teaching methods. 


\section{CONCLUSIONS}

In this study, we set out to ascertain the predictive value of selected student engagement constructs and instructional practices on self-reported outcomes in a general chemistry course delivered using a team-based learning approach. Our study supports the notion that students' learning is primarily influenced by their feelings about their learning environment. The team-based learning approach used in this study provides an environment that encourages collaboration within each learning team and between different teams. Participating in team discussions during the readiness assurance process (i.e., team quizzes) and during problem-solving activities helps students realize that they can achieve higher levels of understanding of the course material through cooperative learning. The more students indicated feeling that the TBL approach was beneficial, the more they likely perceived this pedagogical method as beneficial to their learning needs, thus developing a positive view of the learning environment. Our findings corroborate past research; for example, Fassinger's (1995) and Nunn's (1996) studies reported that among the strongest predictors of classroom participation were students' perceptions that the classroom environment is supportive.

The second most important factor predicting students' perceived learning is their view of the instructor's interest and investment in their learning. An instructor who clearly explains course goals and expectations, uses illustrations to explain difficult points, provides immediate and frequent feedback on course assignments and assessments, incorporates activities that promote self-reflection, and encourages collaboration among students, positively relates to students' perceived learning outcomes. These findings are in line with evidence from other research showing that instructor-student interaction, guiding learning rather than lecturing, and giving specific and timely feedback and encouragement positively influence student development (Cabrera et al., 2001). Likewise, Chickering and Gamson (1987) advocated that instructors who encourage contact between students and faculty, develop reciprocity and cooperation among students, encourage active learning techniques, integrate prompt feedback, emphasize time on task, hold high expectations, and promote respect for diverse talents and ways of learning promote high levels of student engagement and satisfaction, learning, development on a variety of dimensions, and persistence.

The findings in this study corroborate the theoretical-affective perspective proposed by Springer (1999) to describe the effects of small-group learning on academic achievement. Positive learning outcomes can be enhanced when instructors focus on being facilitators for learning rather than on serving as indubitable experts on the subject matter, concentrate time and energy on providing a learning environment and strategies that allow students to take active roles in the learning process and to be accountable for their own and their peers' learning. Since-according to our findings - the constructs that best predict students' learning outcomes are their feelings about the learning environment and extent of perceived instructional guidance, we believe that instructors should give careful consideration to these factors when developing, implementing, and refining team-based learning approaches.

\section{ACKNOWLEDGEMENTS}

This study was funded by a Course Redesign Grant awarded to the first author from the North Carolina General Administration and supported by the Department of Chemistry and the Office for Faculty Excellence at East Carolina University and by the Indiana University Center for Postsecondary Research. All authors made equal contribution. 
Rosa Alvarez-Bell is a Teaching Assistant Professor in Chemistry and the Coordinator of the General Chemistry Laboratories at East Carolina University (Greenville, NC, USA).

Derrick Wirtz is a Senior Instructor in Psychology and the Director of the Psychological Science Ph.D. Program at the University of British Columbia (Kelowna, BC, Canada).

Hui Bian is a Research and Statistics Consultant in the Office for Faculty Excellence at East Carolina University (Greenville, NC, USA).

\section{REFERENCES}

Abrams, H. G., \& Jernigan, L. P. (1984). Academic support services and the success of high-risk college students. American Educational Research Journal, 21(2), 261-274.

ACT. (2002). Mathematics and science achievement and course-taking for college-bound high school students. Retrieved from https://forms.act.org/research/researchers/briefs/2002-2.html

Anaya, G. (1999). College impact on student learning: Comparing the use of self-reported gains, standardized test scores, and college grades. Research in Higher Education, 40(5), 499-526.

Artino, A.R. (2007). Self-regulated learning in online education: A review of the empirical literature. International Journal of Instructional Technology and Distance Learning 4(16). 3-18.

Astin, A. W. (1984). Student involvement: A developmental theory for higher education. Journal of College Student Development, 40, 518-529.

Astin, A. W. (1993). What matters in college?: Four critical years revisited (Vol. 1). San Francisco, CA: Jossey-Bass.

Bandura, A. (1994). Self-efficacy. In R. J. Corsini (Ed.), Encyclopedia of psychology (2 ${ }^{\text {nd }}$ ed., Vol 3, pp. 368-369). New York: Wiley.

Bean, J. (2005). A conceptual model of college student engagement. Paper presented at the Annual Meeting of the Association for the Study of Higher Education, Philadelphia, PA.

Beatty, S. J., Kelley, K. A., Metzger, A. H., Bellebaum, K. L., \& McAuley, J. W. (2009). Team-based learning in therapeutics workshop sessions. American Journal of Pharmaceutical Education, 73(6), 1-7

Best, R. M., Rowe, M., Ozuru, Y., \& McNamara, D. S. (2005). Deep-level comprehension of science texts: The role of the reader and the text. Topics in Language Disorders, 25(1), 65-83.

Cabrera, A. F., Colbeck, C. L., \& Terenzini, P. T. (2001). Developing performance indicators for assessing classroom teaching practices and student learning. Research in Higher Education, 42(3), 327-352.

Chickering, A. W., \& Gamson, Z. F. (1987). Seven principles for good practice in undergraduate education. $A A H E$ bulletin, 3-7.

Clark, M. C., Nguyen, H. T., Bray, C., \& Levine, R. E. (2008). Team-based learning in an undergraduate nursing course. Journal of Nursing Education, 47(3), 111-117.

Clair, K. S., \& Chihara, L. (2012). Team-based learning in a statistical literary class. Journal of Statistics Education, 20(1), 1-20.

Dana, S. W. (2007). Implementing team-based learning in an introduction to law course. Journal of Legal Studies Education, 24(1), 59.

Dorman, C. F., Elith, J., Bacher, S. Buchmann, C., Carl, G., Carre, G. \& Munkemuller, T.

(2013). Collinearity: A review of methods to deal with it and a simulation study evaluating their performance. Ecography, 36(1), 27-46.

Drummond, C. K. (2012). Team-based learning to enhance critical thinking skills in entrepreneurship education. Journal of Entrepreneurship Education, 15, 57-60.

Fassinger, P.A. (1995). Understanding classroom interaction: Students' and professors' contributions to students' silence. The Journal of Higher Education, 82-96.

Field, A. (2009). Discovering statistics using SPSS. Thousand Oaks, CA: Sage publications.

Fink, L. D. (2002). Beyond small groups: Harnessing the extraordinary power of learning teams. In Michaelsen, L. K., Knight, A. B., \& Fink, L. D. (Eds.), Team-based learning: A transformative use of small groups (pp. 3-26). Westport, CT: Greenwood publishing group.

Fink, L. D. (2007). The power of course redesign to increase student engagement and learning. Peer Review, 9(1), 13-17.

144 Alvarez-Bell, R., Wirtz, D., \& Bian, H. (2017). Identifying keys to success in innovative teaching: Student engagement and instructional practices as predictors of student learning in a course using a team-based learning approach. Teaching \& Learning Inquiry, 5(2). http://dx.doi.org/10.20343/teachlearninqu.5.2.10 
Friday, E., Friday-Stroud, S. S., Green, A. L., \& Hill, A. Y. (2006). A multi-semester comparison of student performance between multiple traditional and online sections of two management courses. Journal of Behavioral and Applied Management, 8(1), 66-81.

Grant-Vallone, E. (2011). Successful group work: Using cooperative learning and team-based learning in the classroom. Journal on Excellence in College Teaching, 21(4), 99-121.

Guthrie, J. T., Anderson, E., Alao, S., \& Rinehart, J. (1999). Influences of concept-oriented reading instruction on strategy use and conceptual learning from text. The Elementary School Journal, 99(4), 343-366.

Haidet, P., \& Facile, M. L. (2006). Team-based learning: A promising strategy to foster active learning in cancer education. Journal of Cancer Education, 21(3), 125-128.

Haidet, P., Morgan, R. O., O'Malley, K., Moran, B.J., \& Richards, B. F. (2004). A controlled trial of active versus passive learning strategies in a large group setting. Advances in Health Sciences Education, 9(1), 15-27.

Hadwin, A. F., Järvelä, S., \& Miller, M. (2011). Self-regulated, co-regulated, and socially shared regulation of learning. Handbook of Self-Regulation of Learning and Performance, 30, 65-84.

Hutcheson, G. D., \& Sofroniou, N. (1999). The multivariate social scientist: Introductory statistics using generalized linear models. Thousand Oaks, CA: Sage.

Jacobson, T. E. (2011). Team-based learning in an information literacy course. Communications in Information Literacy, 5(2), 82-101.

Johnson, D. W., \& Johnson, R. (1985). Classroom conflict: Controversy versus debate in learning groups. American Educational Research Journal, 22(2), 237-256.

Johnson, D. W., Johnson, R., \& Smith, K. A. (2014). Cooperative learning: Improving University instruction by basing practice on validated theory. Journal on Excellence in College Teaching, 25(3\&4), 85-118.

Johnson, D. W., Maruyama, G., Johnson, R., Nelson, D., \& Skon, L. (1981). Effects of cooperative, competitive, and individualistic goal structures on achievement: A meta-analysis. Psychological Bulletin, 89(1), 47-62.

Kitsantas, A., Zimmerman, B. J., \& Cleary, T. (2000). The role of observation and emulation in the development of athletic self-regulation. Journal of Educational Psychology, 92(4), 811-8-817.

Knabb, M. T. (2000). Discovering teamwork: A novel cooperative learning activity to encourage group interdependence. The American Biology Teacher, 62(3), 211-213.

Koles, P. G., Stolfi, A., Borges, N. J., Nelson, S., \& Parmelee, D. X. (2010). The impact of team-based learning on medical students' academic performance. Academic Medicine, 85(11), 1739-1745.

Kuh, G. D., Cruce, T. M., Shoup, R., Kinzie, J., \& Gonyea, R. M. (2008). Unmasking the effects of student engagement on first-year college grades and persistence. The Journal of Higher Education, 79(5), 540563.

Meyers, L. S., Gamst, G., \& Guarino, A. J. (2006). Applied multivariate research: Design and interpretation. Thousand Oaks, CA: Sage.

Michaelsen, L. K., Knight, A. B., \& Fink, L. D. (Eds.). (2002). Team-based learning: A transformative use of small groups. Westport, CT: Greenwood publishing group.

National Survey of Student Engagement. 2012. Retrieved from http://nsse.indiana.edu/html/

Nunn, C. E. (1996). Discussion in the college classroom: Triangulating observational and survey results. The Journal of Higher Education, 67(3), 243-266.

Oakes, J. (1990). Opportunities, achievement, and choice: Women and minority students in science and mathematics. Review of Research in Education, 16(1), 153-222.

O'Connor, B. P. (2000). SPSS and SAS programs for determining the number of components using parallel analysis and Velicer's MAP test. Behavior Research Methods, Instruments, \& Computers, 32(3), 369-402.

Osborne, J. W., \& Costello, A. (2009). Best practices in exploratory factor analysis: Four recommendations for getting the most from your analysis. Pan-Pacific Management Review, 12(2), 131-146.

Parmelee, D. X., DeStephen, D., \& Borges, N. J. (2009). Medical students' attitudes about team-based learning in a pre-clinical curriculum. Medical Education Online, 14, 1.

Parmelee, D. X., \& Michaelsen, L. K. (2010). Twelve tips for doing effective team-based learning (TBL). Medical Teacher, 32(2), 118-122.

Pascarella, E. T., \& Terenzini, P. T. (2005). How college affects students: A third decade of research (Vol. 2). San Francisco, CA: Jossey-Bass.

Paterson, J., \& Sneddon, J. (2011). Conversations about curriculum change: Mathematical thinking and teambased learning in a discrete mathematics course. International Journal of Mathematical Education in Science and Technology, 42(7), 879-889.

Alvarez-Bell, R., Wirtz, D., \& Bian, H. (2017). Identifying keys to success in innovative teaching: Student engagement and instructional practices as predictors of student learning in a course using a team-based learning approach. Teaching \& Learning Inquiry, 5(2). http://dx.doi.org/10.20343/teachlearninqu.5.2.10 
Pekrun, R. (2006). The control-value theory of achievement emotions: Assumptions, corollaries, and implications for educational research and practice. Educational Psychology Review, 18(4), 315-341.

Pekrun, R., \& Perry, R. (2014). Control-value theory of achievement emotions. International Handbook of Emotions in Education, 120-141.

Pett, M. A., Lackey, N. R., \& Sullivan, J. J. (2003). Making sense of factor analysis: The use of factor analysis for instrument development in health care research. Thousand Oaks, CA: Sage.

Pike, G. R. (2011). Using college students' self-reported learning outcomes in scholarly research. New Directions for Institutional Research, 2011(150), 41-58.

Pintrich, P. R., \& De Groot, E. V. (1990). Motivational and self-regulated learning components of classroom academic performance. Journal of Educational Psychology, 82(1), 33-40.

Prince, M. (2004). Does active learning work? A review of the research. Journal of engineering education, 93(3), 223-231.

Rassuli, A., \& Manzer, J. P. (2005). "Teach us to learn": Multivariate analysis of perception of success in team learning. Journal of Education for Business, 81(1), 21-27.

Rotter, J. B. (1966). Generalized expectancies for internal versus external control of reinforcement. Psychological Monographs: General and Applied, 80(1), 1-28.

Schreiner, L. A., \& Louis, M. C. (2011). The engaged learning index: Implications for faculty development. Journal on Excellence in College Teaching, 22(1), 5-28.

Skinner, E. A., \& Belmont, M. J. (1993). Motivation in the classroom: Reciprocal effects of teacher behavior and student engagement across the school year. Journal of Educational Psychology, 85(4), 571-581.

Smith, K., Johnson, D. W., \& Johnson, R. T. (1981). Can conflict be constructive? Controversy versus concurrence seeking in learning groups. Journal of Educational Psychology, 73(5), 651-663.

Springer, L., Stanne, M. E., \& Donovan, S. S. (1999). Effects of small-group learning on undergraduates in science, mathematics, engineering, and technology: A meta-analysis. Review of Educational Research, 69(1), 2151.

Stevens, J. P. (2012). Applied multivariate statistics for the social sciences. New York, NY: Routledge.

Svanum, S., \& Bigatti, S. M. (2009). Academic course engagement during one semester forecasts college success: Engaged students are more likely to earn a degree, do it faster, and do it better. Journal of College Student Development, 50(1), 120-132.

Thomas, M. D., \& McPherson, B. J. (2011). Teaching positive psychology using team-based learning. The Journal of Positive Psychology, 6(6), 487-491.

Thomas, T. (2012). Adapting team-based learning to the interpersonal communication class. International Journal of Pedagogies and Learning, 7(1), 51-61.

Thompson, B. M., Schneider, V. F., Haidet, P., Perkowski, L. C., \& Richards, B. F. (2007). Factors influencing implementation of team-based learning in health sciences education. Academic Medicine, 82(10), S53S56.

Zimmerman, B. J. (2002). Becoming a self-regulated learner: An overview. Theory Into Practice, 41(2), 64-70.

Zwaan, R. A., \& Singer, M. (2003). Text comprehension. In Graesser, A. C., Gernsbacher, M. A., and Goldman, S. R. (Eds.). Handbook of discourse processes (Vol 3, pp. 83-121). New Jersey: Lawrence Erlbaum Associates, Inc.

Copyright for the content of articles published in Teaching \& Learning Inquiry resides with the authors, and copyright for the publication layout resides with the journal. These copyright holders have agreed that this article should be available on open access under a Creative Commons Attribution License 4.0 International (https://creativecommons.org/licenses/by/4.0). The only constraint on reproduction and distribution, and the only role for copyright in this domain, should be to give authors control over the integrity of their work and the right to be properly acknowledged and cited, and to cite Teaching \& Learning Inquiry as the original place of publication. Readers are free to share these materials - as long as appropriate credit is given, a link to the license is provided, and any changes are indicated. instructional practices as predictors of student learning in a course using a team-based learning approach. Teaching \& Learning Inquiry, 5(2). http://dx.doi.org/10.20343/teachlearninqu.5.2.10 